\title{
LIPID ESTIMATION IN CIRCUMONCO BOTHRIUM SINGHII N.SP.
}

\author{
R.R. Dandwate \\ Arts, Commerce \& Science College, Sonai Tal. Newasa Dist. .Amednagar (MS) \\ Email : drajendra2006@gmail.com \\ Communicated: 28.07.20 \\ Revision: 09.08.20 \& 26.8.2020 \\ Accepted: 11.09 .2020 \\ Published: 30.09.2020
}

\begin{abstract}
ABSTARCT
The present parasite is endoparasite of Mastacembalus armatus, a fresh water fish found in a Savitri river, Kokan. The parasite absorb the lipids from host due to which the lipid in host body get decreases and in body of parasite i.e. circumoncobothrium singhii n.sp get increases. Present paper deals with biochemical estimation of lipid from Circumoncobothrium singhii $n . s p$ its results shows that the percentage of lipid is high in parasites as compared to their hosts. Parasite absorbing most of nourshing from host and fulfilling its need and causing hinderence in the proper development of host.
\end{abstract}

Key words: - Host, lipid, cestode, intestine, endoparasites.

\section{INDRODUCTION:}

The genus Circumonco bothrium is erected by Shinde G.B., (1968). From the intestine of fresh water fish Ophiocephalus leuconpunctatus as a type species $C$. ophiocephali. Shinde and Jadhav 1976 reported C. described two new species of this genus $C$. aurangabadensis and $C$. raoi from Mastacembellus armatus. Jadhav and Shinde, 1976 reported C. gachuai from Ophiocephalus gauchua.

Lipid metabolism in cestodes has been worked out to only a limited extent. But gas chromatography and column chromatography have revolution lipid analysis. The role of lipids in cestode metabolism is not clear, there is no evidence for example that lipid act as an energy reserves in cestodes as they do in nematodes. The synthesis of lipids is only studied in $\mathrm{H}$. diminuta (Ginger and Fairbairn, 1966 b). In this species only a limited capacity for fatty acids biosynthesis has been demonstrated and most of its fatty acids appear to be desired from the host.

\section{MATERIAL AND METHODS:}

The infected fishes were collected from Savitri river in Kokan area. During January, 2016December, 2016. Thirteen intestines of Mastacembalus armatus were dissected. Out of these intestines seven intestines found to be heavily infected with Cestode parasites. Small pieces of infected intestines were also collected to estimate the lipid content from host intestine. The identical worms were collected and observed under the microscope and preserved in $4 \%$ formalin for taxonomic studies. The Morphological observations turns them to n. sp. of genus Circumonco bothrium, Shinde, 1968. The lipid content in cestode parasites and host intestines was estimated by Folch et. al. 1957 method.

\section{DESCRIPTION:}

The worms were kept on blotting paper for removing the excess water then these worms were kept in watch glass and wet weight of them taken, then they were kept in Oven at $60^{\circ} \mathrm{c}$ until tissue become dry. $50 \mathrm{mg}$ of tissue taken in a centrifuge tube and analysed for lipid content. 
The tissue was homogenized with chloroform: Methanol (2:1) mixture and $0.2 \mathrm{ml}$ of $\mathrm{Nacl}(0.9 \%)$ was added and centrifuged for 5 minutes at 3000 RPM. The lower phase comprising of chloroform methanol layer contained all the lipid was separated and evaporated at room temp. over night. To this test tube $2 \mathrm{ml}$ Con $\mathrm{H}_{2} \mathrm{SO}_{4}$ was added and boiled for 10min. in a water bath and cooled. The sample volume $0.1 \mathrm{ml}$ was taken in clean test tube and made up to $1 \mathrm{ml}$ with concentrated $\mathrm{H}_{2} \mathrm{SO}_{4}$ acid to which $2.5 \mathrm{ml}$ of Phosphovanillin reagent was added and incubated for 30 minutes. The colour developed was read $53 \mathrm{~nm}$ in a colorimeter against reagent blank. The amount of lipid was determined by referring to the standard graph prepared by using cholesterol as standard lipid. The standard graph was prepared by plotting concentration of standard on " $\mathrm{X}$ " axis and O.D. on "Y" axis.

The lipid concentration was expressed as $\mathrm{mg} / \mathrm{gm}$ wet weight of the tissue.

\section{Formula:}

$\%$ Lipid = O.D. of sample $\times$ Con. of Standard.

$$
=\frac{1.35 \times 0.07}{0.25} \times 100
$$

$=37.80 \mathrm{mg} / \mathrm{gm}$ of wet weight of tissue.

The lipid amount of host intestine of Mastacembalus armatus is estimated by same procedure. The obtained result showed that the intestine passes lipid $34.09 \mathrm{mg} / \mathrm{gm}$ of wet weight of tissue.

\section{CONCLUSION:}

By present biochemical estimation of lipid it is concluded that the percentage of lipid is high in parasites as compared to their hosts. Parasite absorbing most of nourshing from host and fulfilling its need and causing hinderence in the proper development of host.

\section{ACKNOWLEDGEMENT}

Authors thankful to Principal, Arts, Commerce and Science College, Sonai, laboratory facilities.

\section{REFERENCES:}

Barnes, H. and Blackstock, J. (1973): Estimation of lipids in marine animals. Detailed investigations of sulphos phosphovanillin method for (total) lipid.J. Exp. Mar. Biol. Ecol. 12: 103118.

Engelbrecht, H. and Buske, M. (1981): Glycogen and Fat in the development cycle of helminthes. Angew. Parasitol. 22(4): 199-204.

Jadhav, B.V., Shinde G.B. and Kadam, S.S. (1980): Lipid percentage variation according to the seasons of Stilesia leiperi from ovaris bharal at Aurangabad. Biology Journal. Vol. II No. 4: 39-41.

Tat, M.B. and Jadhav, B.V. (2004): A new species of the genus Circumonco bothrium, Shinde (1968) Cestoda: Pseudophyllidea, Carus (1863) from Ophiocephalus gachua at Dhanegaon, Dist. Beed, M.S. N.J. of life science 1 (1), 2004, (129-132).

Tat, M.B. and Jadhav, B.V. (1997): Senga mohekarae n. sp. (Cestoda: Ptychobothridae) from Mastacembellus armatus. Rivista di parasitologia Vol. XVII (LVII)-N-2 AGOSTO.

Wongswad, C and Jadhav, B.V. (1998): Circumonco bothrium baimaii n.sp. (Cestoda: Pseudophyllidea) from a fresh water fish, Maesa Stream, Chiang Mai, Thailand. Rivista Di Parastologia, Vol. XV (LIX) N-3 December, 1998 
I J R B A T, Issue (VIII), Vol. III, Sept 2020: 192-194

A Double-Blind Peer Reviewed \& Refereed Journal
OPEN $\bigcirc$ ACCESS

e-ISSN 2347 - 517X

Original Article

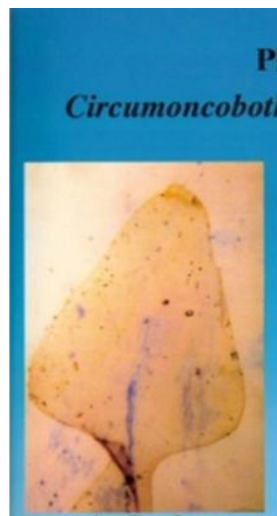

A. Scolex

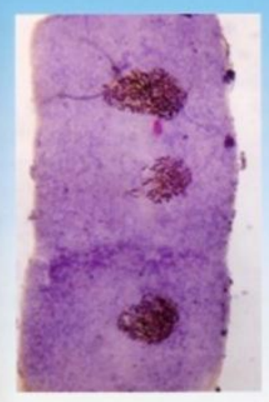

C. Mature segement D. Gravid segement

\section{Plate-I}

singhï n.sp.

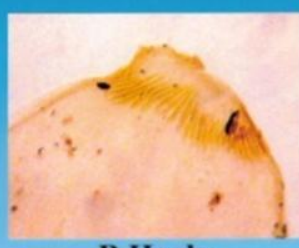

B.Hooks

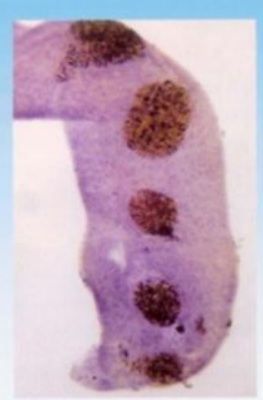

Parasite-Circumonco bothrium singhiin

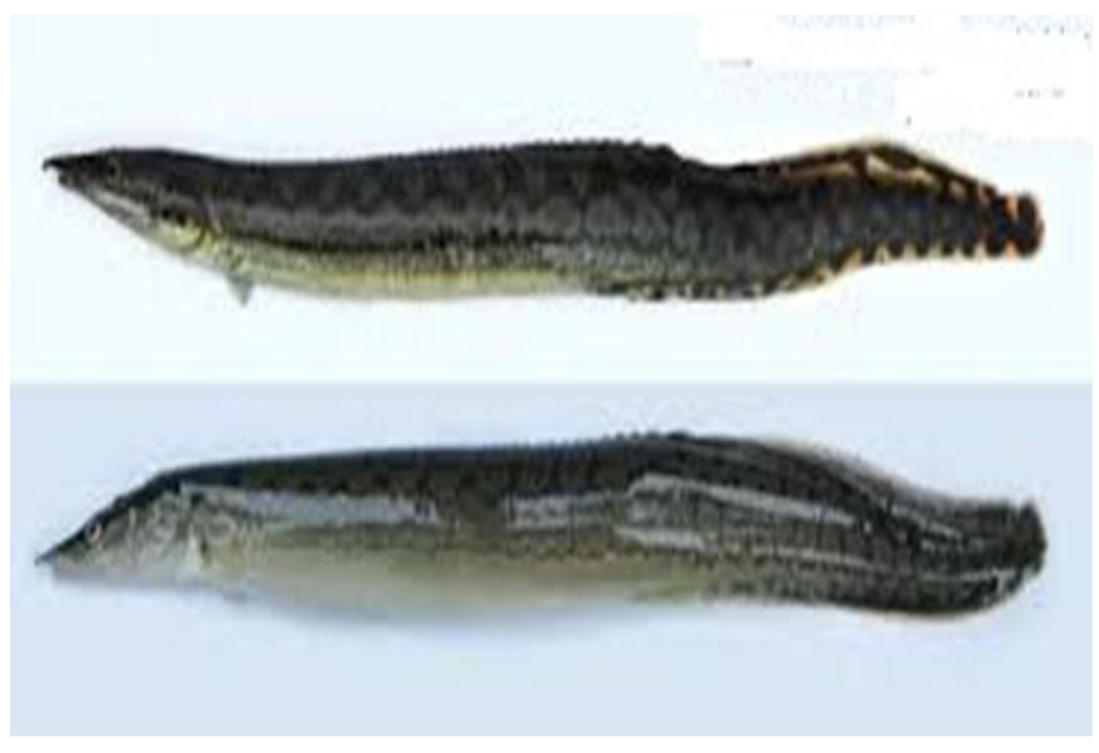

Parasite- Circumonco bothrium singhii n.sp

Host - Mastacembalus armatus 